\title{
PARTISIPASI MASYARAKAT GAMPONG TGK DILAWEUNG TERHADAP PELESTARIAN TERUMBU KARANG DI KECAMATAN MUARA TIGA KABUPATEN PIDIE
}

\author{
Novia Zalmita ${ }^{1 *}$, M. Hafizul Furqan ${ }^{2}$, Zul Usrati $^{3}$ \\ 1,2,3Program Studi Pendidikan Geografi, FKIP, Universitas Syiah Kuala \\ *noviazalmita@unsyiah.ac.id
}

\begin{tabular}{lrc}
\hline \multicolumn{3}{c}{ INFO ARTIKEL } \\
\hline \multicolumn{2}{l}{ Riwayat Artikel: } \\
Dikirim $\quad:$ & $04-05-2020$ \\
Disetujui & $:$ & $08-06-2020$ \\
Diterbitkan & $:$ & $26-06-2020$ \\
\hline
\end{tabular}

Kata kunci:

Partisipasi, Pelestarian,

Terumbu Karang, Tangga partisipasi Arnstein.

\begin{abstract}
ABSTRAK
The existence of coral reefs really helps the lives of people around the coast, such as the village of Tgk Dilaweung which is located in the coastal area. The purpose of this study was to determine the participation of the community in Gampong Tgk Dilaweung towards the preservation of coral reefs in Muara Tiga sub-district, Pidie district. To achieve this goal, 30 respondents were selected from the Gampong Tgk Dilaweung community around the coast using purposive sampling technique. This research uses descriptive analysis method to describe the community participation of Gampong Tgk Dilaweung towards the preservation of coral reefs. The data was collected by distributing questionnaires to respondents based on Arnstein's eight ladder of participation so that they can be categorized into 2 levels of participation, namely high, medium and low. From the results of data processing, it was found that all participation indicators given to 30 respondents were in medium and high positions. The highest percentage is in consultation resistance (87.8\%) and is in the high category, while the lowest percentage is in the therapy and delegation stages of power (70\%) but is still in the moderate category. Based on these data, it was concluded that the people of Gampong Tgk Dilaweung participated in protecting the coral reefs in the area.
\end{abstract}

Keberadaan terumbu karang sangat membantu kehidupan masyarakat di sekitar pesisir seperti gampong Tgk Dilaweung yang terletak di daerah pesisir. Tujuan dari penelitian ini adalah untuk mengetahui partisipasi masyarakat Gampong Tgk Dilaweung terhadap kelestarian terumbu karang di kecamatan Muara Tiga Kabupaten Pidie. Untuk mencapai tujuan tersebut, maka dipilih 30 responden dari masyarakat Gampong Tgk Dilaweung di sekitar pesisir pantai dengan menggunakan teknik sampling purposive. Penelitian ini menggunakan metode deskriptif analisis untuk dapat menggambarkan partisipasi masyarakat Gampong Tgk Dilaweung terhadap kelestarian terumbu karang. Pengumpulan data dilakukan dengan menyebarkan kuesioner kepada responden berdasarkan delapan tangga partisipasi Arnstein sehingga dapat dikategorikan menjadi 2 tingkatan partisipasi, yaitu tinggi, sedang dan rendah. Dari hasil pengolahan data didapatkan seluruh indikator partisipasi yang diberikan kepada 30 responden berada pada posisi sedang dan tinggi. Persentase tertinggi berada pada tahan konsultasi $(87,8 \%)$ dan termasuk dalam kategori tinggi, sedangkan persentase terendah berada pada tahapan terapi dan pendelegasian kekuasaan (70\%) tetapi masih berada pada kategori sedang. Berdasarkan data tersebut diambil kesimpulan bahwa masyarakat Gampong Tgk Dilaweung berpartisipasi dalam menjaga terumbu karang didaerah tersebut. 


\section{PENDAHULUAN}

Negara Indonesia adalah negara dengan kepulauan terbesar di dunia, yang memiliki panjang garis pantai lebih dari 99.093 $\mathrm{km}$ dan lebih dari 17,504 pulau. Karena wilayahnya yang cukup luas, maka tidak heran jika Indonesia memiliki kekayaan sumber daya hayati laut yang cukup besar diantaranya adalah terumbu karang. Saat ini lebih dari 284.300 $\mathrm{km}^{2}$ terumbu karang terdapat di Indonesia. Sebagian besar terumbu karang ini bertipe terumbu karang tepi (fringing feefs), yang berdekatan dengan garis pantai dan mudah diakses.

Kondisi terumbu karang di indonesia sebagiannya telah mengalami kerusakan karena faktor alam dan aktifitas manusia. Lembaga Ilmu Pengetahuan Indonesia (LIPI) mengungkapkan bahwa $30,76 \%$ terumbu karang di Indonesia dalam keadaan yang kurang baik atau rusak, sedangkan 5,54 \% dalam kondisi sangat baik, 26,95\% berkondisi baik sementara 36,90\% berkondisi cukup baik.

Rusaknya terumbu karang disebabkan oleh dua faktor yaitu: faktor alam dan faktor manusia, Salah satu kerusakan yang terjadi karena ulah manusia yaitu praktek penangkapan ikan yang merusak. Dengan meningkatnya jumlah penduduk juga menyebabkan kenaikan permintaan terhadap sumberdaya ikan. Hal ini menyebabkan pola pemanfaatan sumberdaya perikanan yang berlebihan dan tidak memperhatikan aspek daya dukung lingkungan sehingga dapat mengganggu ekosistem pesisir dan laut yaitu terumbu karang. Penangkapan ikan yang menggunakan bahan berbahaya seperti bom peledak, racun sianida, menggunakan jaring harimau, dan lain sebagainya. Semakin rusaknya terumbu karang maka akan memberi dampak yang buruk terhadap masyarakat disekitar pesisir pantai yang umumnya menggantungkan kehidupan mereka pada pemanfaatan sumber daya hayati laut.

Gampong Tgk Dilaweung adalah sebuah gampong yang terletak diwilayah kecamatan Muara Tiga Kabupaten Pidie yang memiliki potensi terumbu karang yang cukup baik. Untuk menjaga dan melestarikan terumbu karang diwilayah itu perlunya tingkat kesadaran yang tinggi serta partisipsi dari masyarakat sekitar daerah pesisir pantai tersebut yaitu masyarakat Gampong Tgk Dilaweung.

Partisipasi masyarakat dapat diartikan sebagai proses dimana warga atau masyarakat mengambil peran serta ikut aktif dalam proses perencanaan, pelaksanaan, dan peninjauan kebijakan yang langsung mempengaruhi kehidupan mereka (Soemarto, 2009). Partisipasi dapat menumbuhkan sense of community yang dapat membentuk dan mendorong integritas sosial dalam masyarakat (Ashari, 2013). Partisipasi masyarakat dapat dikembangkan melalui suatu komunitas tertentu dengan menciptakan peran masyarakat yang maksimal dengan tujuan agar semua orang dalam masyarakat tersebut dapat dilibatkan secara aktif pada proses dalam suatu kegiatan terencana (Nasdian, 2014). Dengan demikian dalam pelaksanaanya, masyarakat yang merupakan pengguna utama sumber daya laut, diharapkan terlibat aktif dalam perencanaan, pelaksanaan, dan pemantauan pengelolaan terumbu karang yang ada di wilayahnya (Widayatun, 2011).

Bentuk peran serta masyarakat dalam pengelolaan dan pelestarian lingkungan hidup khususnya terumbu karang perlu dibina dan dikembangkan dalam bidang administratif dengan berbagai cara sesuai dengan pengetahuan dan pengalaman anggota masyarakat yang bersangkutan. Peran tersebut dapat berupa (1) Memberi informasi kepada pemerintah, (2) Meningkatkan kesediaan masyarakat untuk menerima keputusan, (3) Membantu perlindungan hukum, dan (4) Mendemokrasikan pengambilan keputusan (Hardjasoemantri, 1995)

Untuk mengetahui seberapa besar partisipasi masyarakat, Arnstein (1969) menawarkan suatu teori yang disebut dengan teori The Ladder of Participation yaitu suatu gradasi atau tahapan-tahapan partisipasi masyarakat. partisipasi masyarakat ini dikategorikan menjadi delapan tahap. Kedelapan tahap ini merupakan alat analisis untuk mengidentifikasi partisipasi masyarakat. Tahapan tersebut dapat dilihat dalam gambar delapan tangga partisipasi Arnstein berikut. 


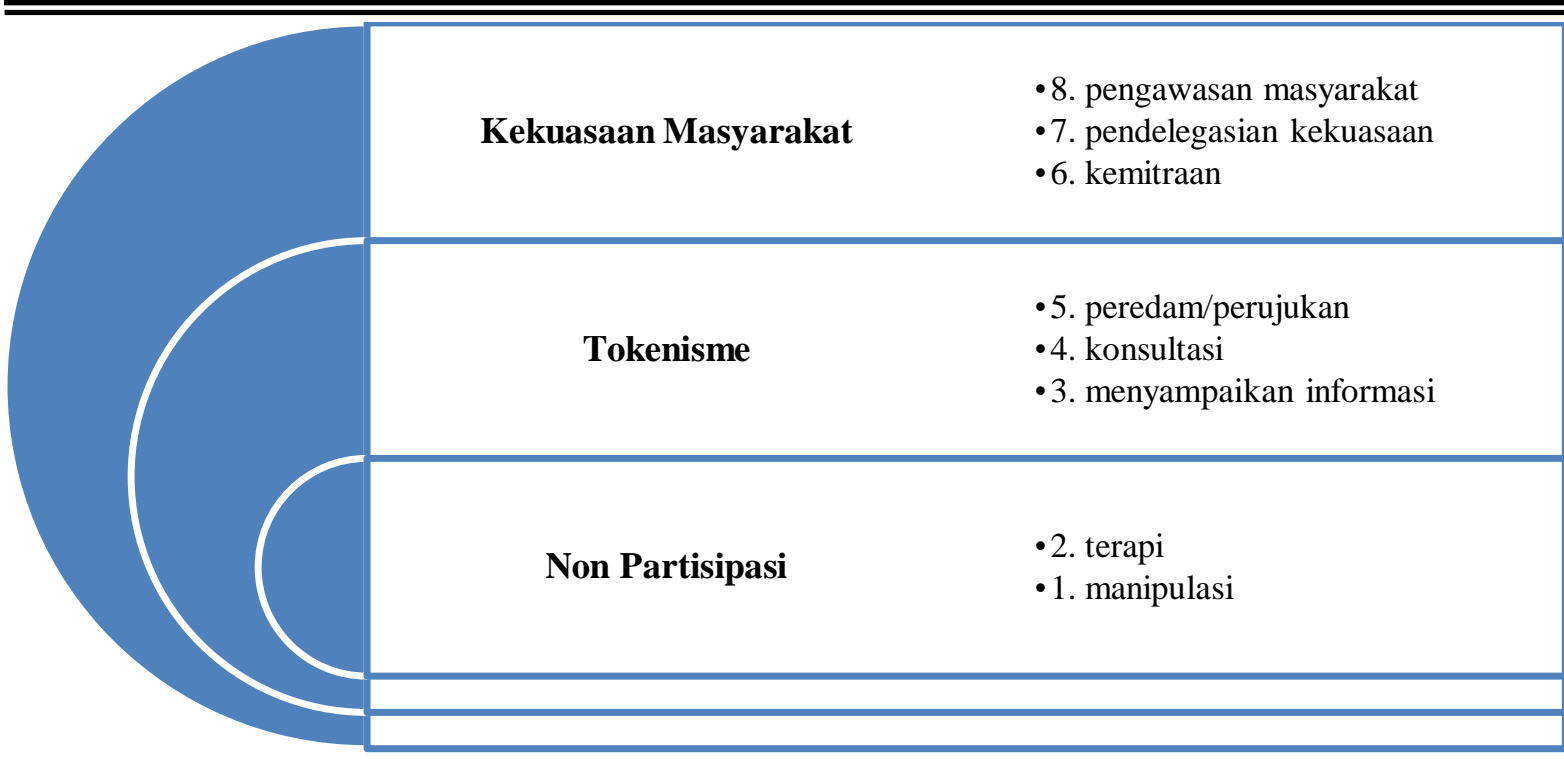

Sumber: Arnstein, 1969.

Berdasarkan gambar tersebut Arnstein memberikan gambaran yang sangat jelas tentang jenjang partisipasi masyarakat dalam kehidupan nyata dengan demikian pola masyarakat akan mengikuti alur secara bertahap atau bertingkat dari tangga pertama sampai tangga kedelapan (Satries, 2010). Tangga pertama yaitu manipulasi atau penyalahgunaan serta tangga kedua terapi (perbaikan) tidak termasuk dalam konteks partisipasi yang sesungguhnya. Di dalam hal ini masyarakat terlibat dalam suatu program, akan tetapi sesungguhnya keterlibatan mereka tidak dilandasi oleh suatu dorongan mental, psikologis, dan disertai konsekuensi keikutsertaan yang memberikan kontribusi dalam program tersebut. Masyarakat pada posisi ini hanyalah menjadi obyek dalam program.

Tangga ketiga, pemberian informasi dilanjutkan tangga ke empat konsultasi dan tangga kelima peredaman kemarahan/ penentraman adalah suatu bentuk usaha untuk menampung ide, saran, masukan dari masyarakat untuk sekedar meredam keresahan masyarakat. Oleh karena itu, tangga ini masuk dalam kategori tokenisme (pertanda). Sesungguhnya penyampaian informasi atau pemberitahuan adalah suatu bentuk pendekatan kepada masyarakat agar memperoleh legitimasi publik atas segala program yang dicanangkan. Konsultasi yang yang disampaikan hanyalah upaya untuk mengundang ketertarikan publik untuk mempertajam legitimasi, bukan untuk secara sungguh-sungguh memperoleh pertimbangan dan menegetahui keberadaan publik. Tangga kelima adalah peredaman yang intinya sama saja dengan kedua tahap sebelumnya. Selanjutnya Arnstein menyebutnya sebagai tingkat penghargaan atau formalitas.

Menurut Arnstein baru pada tangga keenam inilah terjadi partisipasi atau kemitraan masyarakat. Pada tahap ini masyarakat telah mendapat tempat dalam suatu program pembangunan. Pada tangga ketujuh sudah terjadi pelimpahan wewenang oleh pemerintah kepada masyarakat. Yang terakhir masyarakat sudah dapat melakukan kontrol terhadap program pembangunan. Tahap inilah yang disebut dengan partisipasi atau dalam peristilahan Arnstein sebagai kekuasaan masyarakat.

\section{METODE PENELITIAN}

Penelitian ini menggunakan metode penelitian deskriptif analisis untuk mengukur partisipasi masyarakat Gampong Tgk Dilaweung terhadap kelestarian terumbu karang di Kecamatan Muara Tiga Kabupaten Pidie. Penelitian deskriptif analisis bertujuan menggambarkan secara sistematis, akurat dan menyeluruh mengenali suatu populasi atau bidang tertentu dan mengambarkan situasi dan kejadian pada suatu polupasi. Data yang dikumpulkan bersifat deskriptif sehingga tidak 
dimaksudkan mencari penjelasan, menguji hipotesis, membuat prediksi atau mempelajari implikasi (Azwar, 2009).

Kondisi yang digambarkan berupa partisipasi masyarakat terhadap pelestarian terumbu karang di Kecamatan Muara Tiga Kabupaten Pidie. Partisipasi masyarakat tersebut kemudian dianalisis menggunakan delapan tangga atau tingkatan partisipasi masyarakat yang disesuaikan dengan skema tahapan pelestaian terumbu karang. Adapun kedelapan tangga partisipasi masyarakat tersebut dapat dilihat pada tabel 1 .

Untuk mengukur derajat partisipasi masyarakat terhadap pelestarian terumbu karang di Kecamatan Muara Tiga Kabupaten Pidie, maka disusun kuesioner dengan berdasarkan pada tiga tahapan dari Tabel 1 yang telah dimodifikasi menyesuaikan dengan skema tahapan pelestarian terumbu karang sehingga dapat dikategorikan menjadi 2 tingkatan partisipasi, yaitu tinggi, sedang dan rendah.

Penelitian ini dilakukan di Gampong Tgk Dilaweung Kecamatan Muara Tiga Kabupaten Pidie dengan mengambil populasi seluruh penduduk yang berjumlah 603 KK. Dikarenakan populasi terlalu luas maka dibutuhkan sampel yang menjadi perwakilan dari seluruh gambaran populasi, Untuk menentukan sampel maka digunakan teknik pengambilan sampel yaitu Sampling Purposive karena adanya pertimbangan atau karakteristik tertentu yang bertujuan agar data lebih representatif. Karakteristik responden dalam penelitian adalah masyarakat yang mengerti dan berinteraksi langsung dengan terumbu karang serta memiliki pengetahuan terkait dengan pelestarian terumbu karang didaerah tersebut. Responden yang diambil berjumlah 30 orang yang digolongkan dalam tiga golongan yaitu: nelayan (12 orang), pelajar/mahasiswa ( 8 orang), dan masyarakat yang tinggal disekitar pesisir pantai (10 orang).

\section{HASIL DAN PEMBAHASAN}

Dalam penelitian ini 30 orang penduduk Gampong Tgk Dilaweung menjadi responden. Data yang diperoleh dari hasil penelitian dapat memberikan hasil dalam memecahkan permasalahan dalam suatu penelitian. Berdasarkan hasil angket (kuesioner) mengenai penelitian partisipasi masyarakat dalam menjaga kelestarian terumbu karang di Gampong Tgk Dilaweung dapat dilihat dalam rekapitulasi jawaban kuesioner dapat dilihat pada Tabel 2.

Tabel 1. Derajat Partisipasi Masyarakat Gampong Tgk Dilaweung terhadap Kelestarian Terumbu Karang di Kecamatan Muara Tiga Kabupaten Pidie

\begin{tabular}{|c|c|c|c|}
\hline No. & Derajat & Tangga & Indikator penelitian \\
\hline 1 & \multirow{2}{*}{$\begin{array}{l}\text { Non } \\
\text { Partisipasi }\end{array}$} & Manipulasi & Informasi cara melestarikan terumbu karang \\
\hline 2 & & Terapi & $\begin{array}{l}\text { Komunikasi dengan pemerintah terkait pelestarian } \\
\text { terumbu karang }\end{array}$ \\
\hline 3 & \multirow[t]{3}{*}{ Tokenisme } & $\begin{array}{l}\text { Menyampaikan } \\
\text { informasi }\end{array}$ & $\begin{array}{l}\text { Sosialisasi cara melestarikan terumbu karang dari } \\
\text { pemerintah kepada masyarakat }\end{array}$ \\
\hline 4 & & Konsultasi & $\begin{array}{l}\text { Masyarakat memberikan usulan/pendapat secara } \\
\text { langsung atau tidak langsung terkait dengan pelestarian } \\
\text { terumbu karang }\end{array}$ \\
\hline 5 & & $\begin{array}{l}\text { Peredam } \\
\text { kemarahan }\end{array}$ & Pembahasan usulan masyarakat oleh pemerintah \\
\hline 6 & \multirow[t]{3}{*}{$\begin{array}{l}\text { Kekuasaan } \\
\text { Masyarakat }\end{array}$} & Kemitraan & $\begin{array}{l}\text { Masyarakat memiliki andil yang sama dengan } \\
\text { pemerintah dalam mengawasi dan melestarikan } \\
\text { terumbu karang }\end{array}$ \\
\hline 7 & & $\begin{array}{l}\text { Pendelegasian } \\
\text { kekuasaan }\end{array}$ & $\begin{array}{l}\text { Pemerintah telah memberikan wewenang kepada } \\
\text { masyarakat untuk melestarikan terumbu karang }\end{array}$ \\
\hline 8 & & $\begin{array}{l}\text { Pengawasan } \\
\text { masyarakat }\end{array}$ & $\begin{array}{l}\text { Masyarakat dapat terlibat aktif dalam hal merancang, } \\
\text { implementasi, evaluasi dan kontrol setiap kebijakan } \\
\text { yang dibuat mengenai pelestarian terumbu karang }\end{array}$ \\
\hline
\end{tabular}

Sumber: Arnstein, 1969, dimodifikasi 
Tabel 2. Rekapitulasi Jawaban Responden Terhadap Indikator Derajat Partisipasi

\begin{tabular}{|l|l|l|c|}
\hline No & Tangga Arnstein & \multicolumn{1}{|c|}{ Indikator } & Jawaban \\
\hline 1 & Manipulasi & Informasi cara pelestarian terumbu karang & $75 \%$ \\
\hline 2 & Terapi & $\begin{array}{l}\text { Komunikasi dengan pemerintah terkait } \\
\text { pelestarian terumbu karang }\end{array}$ & $70 \%$ \\
\hline 3 & $\begin{array}{l}\text { Menyampaikan } \\
\text { informasi }\end{array}$ & $\begin{array}{l}\text { Sosialisasi cara melestarikan terumbu karang } \\
\text { dari pemerintah kepada masyarakat }\end{array}$ & $80 \%$ \\
\hline 4 & Konsultasi & $\begin{array}{l}\text { Masyarakat memberikan usulan/pendapat secara } \\
\text { langsung atau tidak langsung terkait dengan } \\
\text { pelestarian terumbu karang }\end{array}$ & $87,8 \%$ \\
\hline 5 & Peredam kemarahan & Pembahasan usulan masyarakat oleh pemerintah & $83,3 \%$ \\
\hline 6 & Kemitraan & $\begin{array}{l}\text { Masyarakat memiliki andil yang sama dengan } \\
\text { pemerintah dalam mengawasi dan melestarikan } \\
\text { terumbu karang }\end{array}$ & $88,3 \%$ \\
\hline 7 & $\begin{array}{l}\text { Pendelegasian } \\
\text { kekuasaan }\end{array}$ & $\begin{array}{l}\text { Pemerintah telah memberikan wewenang kepada } \\
\text { masyarakat untuk melestarikan terumbu karang }\end{array}$ & $70 \%$ \\
\hline 8 & $\begin{array}{l}\text { Pengawasan } \\
\text { masyarakat }\end{array}$ & $\begin{array}{l}\text { Masyarakat dapat terlibat aktif dalam hal } \\
\text { merancang, implementasi, evaluasi dan kontrol } \\
\text { setiap kebijakan yang dibuat mengenai } \\
\text { pelestarian terumbu karang }\end{array}$ & $71,7 \%$ \\
\hline
\end{tabular}

Sumber: Pengolahan Data, 2020

Berdasarkan data hasil jawaban dari responden dengan menggunakan 8 indikator derajat partisipasi dari Arnstein tersebut dapat dilihat bawah seluruh indikator yang diberikan kepada 30 responden berada pada posisi sedang dan tinggi. Artinya seluruh indikator derajat partisipasi masyarakat sudah terpenuhi. Kondisi ini menggambarkan bahwa masyarakat Gampong Tgk Dilaweung ikut serta berpartisipasi dalam menjaga kelestarian terumbu karang di Kecamatan Muara Tiga Kabupaten Pidie Hal tersebut dibuktikan dengan melihat besarnya persentase jawaban pada masing-masing butir jawaban. Dengan demikian dapat disimpulkan bahwa sebagian besar responden ikut berpartisipasi dalam menjaga kelestarian terumbu karang.

Partisipasi pemerintah dalam menjaga kelestarian terumbu karang yaitu dengan memberikan bimbingan dan penyuluhan kepada masyarakat mengenai pelestarian terumbu karang. Masyarakat juga ikut mendukung pemerintah dalam menjaga konsevasi laut sehingga dapat meningkatkan kualitas lingkungan sekitar. Masyarakat juga menyambut baik rencana pemerintah tentang pelarangan penggunaan bahan berbahaya seperti bom dan jaring harimau terhadap penangkapan ikan karena dapat merusak terumbu karang.

Masyarakat mempunyai partisipasi penting dalam pelestarian terumbu karang di Kecamatan Muara Tiga Kabupaten Pidie. Tanpa adanya partisipasi serta masyarakat terhadap kelestarian terumbu karang maka terumbu karang dapat terancam rusak. Beberapa partisipasi masyarakat dalam menjaga kelastarian terumbu karang adalah melakukan pencegahan bila ada pihak-pihak yang melakukan kecurangan terhadap penangkapan ikan dengan menggunakan bahan berbahaya seperti bom dan jaring harimau. Masyarakat juga akan melapor kepada yang berwenang bila ada pihak-pihak yang merusak terumbu karang.

Ada beberapa aspek yang sangat penting yang menimbulkan relasi atau hubungan timbal balik antara masyarakat dengan alam sehingga partisipasi masyarakat sangatlah penting dalam menjaga kelestarian terumbu karang. Pada aspek ekologi ekosistem terumbu karang memiliki manfaat yang secara tidak langsung dirasakan oleh masyarakat pesisir khususnya. Ekosistem terumbu karang 
dapat berfungsi sebagai proteksi lingkungan pesisir khususnya dari ancaman erosi akibat gelombang yang besar dan sebagai penyedia sumberdaya ikan.

Tidak hanya aspek ekologi, ekosistem terumbu karang juga sangat berpartisipasi penting pada aspek ekonomi masyakat pesisir. Manfaat terumbu karang secara ekonomi antara lain yaitu terumbu karang merupakan sumber perikanan yang tinggi karena didalamnya terdapat berbagai jenis ikan yang dapat ditangkap untuk berbagai kebutuhan pangan manusia dan pencaharian masyarakat.

Pada tahun 2017 yang lalu masyarakat Gampong Tgk Dilaweung menemukan sekelompok pelaku yang melakukan penangkapan ikan menggunakan bom ikan, pelaku sekitar 6 orang lengkap dengan perlengkapan menyelam. Pelaku dan semua peralatan yang digunakan diamankan oleh warga dan dibawa ke meunasah Gampong Tgk Dilaweung untuk diadili secara hukum adat gampong dan seterusnya diserahkan ke pihak berwajib atau Polsek Muara Tiga. Sampai saat ini masyarakat selalu waspada terhadap pendatang yang berdatangan untuk menangkap ikan di Gampong Tgk Dilaweung guna mencegah terjadinya penangkapan ikan menggunakan bom ikan yang dapat merusak ekosistem dan terumbu karang.

Dampak penggunaan bom terhadap terumbu karang di Gampong Tgk Dilaweung ialah kerusakan karang diperkirakan mencapai $15 \%$. Habitat rusak sehingga ikan berkurang dan sulit diperoleh. Akhirnya nelayan Gampong Tgk Dilaweung harus mencari ikan ke tempat yang lebih jauh. Dari dampak inilah masyarakat sangat dirugikan oleh pelaku penangkapan ikan menggunakan bom ikan dan sejenisnya. Bukan hanya merusak habitat dan ekosistem terumbu karang, ekonomi masyakarat pun terganggu karena dampak yang disebabkan oleh pelaku penangkapan ikan menggunakan bom. Sebelumnya masyarakat hanya mendapatkan sosialisasi dari pemerintah tentang bahaya dan dampak penggunaan bom ikan terhadap kelestarian terumbu karang dan sebagainya, setelah kejadian tersebut masyarakat bisa merasakan dampak nyata dari penggunaan bom ikan yang sangat merugikan lingkungan dan ekonomi masyarakat Gampong Tgk Dilaweung.

\section{SIMPULAN}

Berdasarkan hasil pengolahan data pada penelitian tentang partisipasi masyarakat dalam menjaga kelestarian terumbu karang ini dapat dilihat bahwa seluruh indikator yang diberikan kepada 30 responden berada pada posisi sedang dan tinggi. Artinya seluruh indikator derajat partisipasi masyarakat sudah terpenuhi. Kondisi ini menggambarkan bahwa masyarakat Gampong Tgk Dilaweung ikut serta berpartisipasi dalam menjaga kelestarian terumbu karang di Kecamatan Muara Tiga Kabupaten Pidie. Hal ini dirasa penting dilakukan oleh masyarakat dalam menjaga terumbu karang contohnya mendukung pemerintah dalam menerapkan konservasi laut serta mencegah dan melaporkan apabila ada pihak - pihak yang merusak terumbu karang. Dengan demikian dapat disimpulkan bahwa sebagian besar responden ikut berpartisipasi dalam menjaga kelestarian terumbu karang.

\section{DAFTAR PUSTAKA}

Arnstein. 1969. A Ladder of Citizen Participation. JAIP, Vol. 35, No. 4.

Asjhari, Ahsan. 2013. Pengukuran Tingkat Partisipasi Masyarakat Desa Cibedug, Kabupaten Bogor dalam Pembangunan Jalan Desa Tipe Otta Seal. Jurnal Sosek Pekerjaan Umum, Vol.5 No.2, hal 76139

Azwar, Saifuddin.2009. Metode Penelitian. Yogyakarta : Pustaka Pelajar

Furqan, M. Hafizul, Dkk. 2020. Pemanfaatan SIG Dalam Mengkaji Perubahan Lahan Pertanian Sawah di Aceh Besar. Vol 2, No 2, hal 19-24.

Hardjasoemantri, Koesnadi. 1995. Hukum Perlindungan Lingkungan: Konservasi Sumber Daya Alam Hayati dan 
Ekosistemnya. Yogyakarta: Gadjah Mada University Press

Nasdian, T.F. 2014. Pengembangan masyarakat. Jakarta: Yayasan Pustaka Obor Indonesia

Satries, Ishardino, Wahyu. 2010. Mengukur Tingkat Partisipasi Masyarakat Kota Bekasi Dalam Penyusunan APBD Melalui Pelaksanaan Musrenbang 2010. Jurnal Kybernan, Vol. 2, No. 2, hal. 89130

Sumarto, Hetifah Sj. 2009..Inovasi, Partisipasi, dan Good Governance: 20 Prakarsa inovatif dan Partisipatif di Indonesia Jakarta : Yayasan Obor Indonesia

Widayatun. 2011. Peran Masyarakat Dalam Pelestarian Terumbu Karang dan Dampaknya Terhadap Peningkatan Kesehatan. Jurnal Kependudukan Indonesia Vol. 6 No. 2, hal.06 -10

Zalmita, N, Dkk. 2020. Analisis Perubahan Pengunaan Lahan Menggunakan Sistem Informasi Geografis (SIG) Gampong Alue Naga Kecamatan Syiah Kuala Tahun 2004 - 2019. Jurnal Geografi FIS UNP. Vol 9 No 1, hal 1-9. 